\title{
A Study of the Spelling Errors committed by Students of English in Saudi Arabia: Exploration and Remedial Measures
}

\author{
Paikar Fatima Mazhar Hameed \\ College of Science and Arts, Methnab, Qassim University, Saudi Arabia \\ E-mail: Fatima.paikar8989@gmail.com
}

Doi:10.7575/aiac.alls.v.7n.1p.203

Received: 02/10/2015

URL: http://dx.doi.org/10.7575/aiac.alls.v.7n.1p.203

Accepted: 14/12/2015

\begin{abstract}
The craziness of English spelling has undeniably perplexed learners, especially in an EFL context as in the Kingdom of Saudi Arabia. In these situations, among other obstacles, learners also have to tackle the perpetual and unavoidable problem of MT interference. Sadly, this perplexity takes the shape of a real problem in the language classroom where the English teacher has a tough time rationalizing with the learners why 'cough' is not spelt as /kuf/ or 'knee' has to do with a silent $/ \mathrm{k} /$. It is observed that students of English as second/foreign language in Saudi Arabia commit spelling errors that cause not only a lot of confusion to the teachers but also lower the self-esteem of the students concerned. The current study aims to identify the key problem areas as far as English spelling ability of Saudi EFL learners is concerned. It aims to also suggest remedial and pedagogical measures to improve the learners' competence in this crucial, though hitherto, nascent skill area in the Saudi education system.
\end{abstract}

Keywords: EFL; error-pattern, spelling instructions, orthography, phonology, vocabulary, language skills, language users

\section{Introduction}

I take it you already know

Of tough and bough and cough and dough?

Others may stumble but not you

On hiccough, thorough, laugh and through,

Well done! And now you wish perhaps,

To learn of less familiar traps?

Beware of heard, a dreadful word,

That looks like beard and sounds like bird.

And dead: It's said like bed, not bead-

For goodness sake don't call it 'deed'!

Watch out for meat and great and threat

(They rhyme with suite and straight and debt).

T.S.W.(1970) as quoted in The Study of Language, George Yule (1996)

It is true that English language is a-phonetic and arbitrary. It is also true that the current repertoire of the language has an interesting history of how the words came to be what they are. But till the time that the language adopts phonetic spelling, the English teaching communities have to strive to find answers to this peculiar spelling problem of the learners. The larger aim of this study is also to unearth how the current pedagogy (or lack of it) has contributed to the spelling problem and what can be done to rectify it. One question that faces us at the outset is, "Why this fetish of the teachers with correct spelling?" The answer has many reasons worthy of being recorded.

One, correct spelling has practical value in everyday life. Communication, however minor, relies heavily on one's ability to spell simple words correctly. Two, knowledge of words helps improve one's language. Three, ability with words adds to the power of expression. And four (most importantly in the context of KSA), with spelling proficiency, vocabulary will improve, leading to better fluency and ability of speech.

There can be no doubt that spelling, especially for the EFL learners is one of the most important learning component. With growing globalization, young men and women (more so from the developing or semi-developed countries like KSA) are seeking better employment opportunities across the borders. However, many times these aspirants have failed 
to secure the desirable positions because of misspelled words in a letter of application even if they excel in their particular area of specialization. In fact, even some teachers fail to land up their dream jobs abroad because of spelling errors and wrong choice of words. Even in ordinary casual correspondence spelling errors end up showing the user in a poor light and causing a bad impression which may be irreparable for the simple reason that smaller the error in language use, bigger the negative impact. Spelling and pronunciation errors and malapropisms are clearly a sign of ignorance. For these reasons we need to work diligently on helping the EFL learners in KSA perfect their spelling and knowledge of words needed in daily life.

According to Apel and Masterson (2001) and their views reinforced by studies undertaken in this field by Apel, Masterson and Niessen (2004), patterns of errors can be discerned in English spelling by EFL learners. These errors, they say, reflect (i) poor linguistic competence at different levels; (ii) lack of or poor awareness of phonology; (iii) lack of or poor knowledge of orthography; (iv) poor vocabulary; (v) poor knowledge of morphological and semantic relationships; and (vi) poor knowledge or lower level awareness of mental orthographic images. Research made into this area shows that literary skills that are previously acquired while acquiring the first language (L-1) influence word recognition in Second Language learning (L-2). In still another study by Figueredo (2006), it was revealed that similar influence, as stated by others, of first language (L-1) that is previously acquired by the EFL learners, is manifested on spelling skills in L-2 learning.

This study is an attempt to identify the spelling problems of the EFL students and the reasons behind the spelling errors committed by them. The study would further suggest recommendations on remedial measures regarding approach to EFL teaching and other appropriate measures to be taken to improve the situation that would help the students overcome this problem.

\section{Literature Review}

There have been many studies on the four primary English skills viz. listening, speaking, reading and writing but little has been done in the area of spelling. As English teachers who are sometimes flabbergasted by students' writing that spells Anne Frank's Diary as Anne Frank's Dairy (spelt phonetically!), we cannot dispute the fact that spelling matters, especially in the context of learning a 'foreign language' such as English in KSA.

Abu Seileek (2006) conducted a study to find out the mistakes committed by Jordanian students learning writing English language as second/foreign language. His finding is that most of the EFL Jordanian students face difficulties when they try to write creatively. According to Ibrahem (1978), one of the challenges is with spelling the English words correctly; his view is that learners wrongly spell the words, which result in weird sentences. Abuhamdia (1995) supports and reinforces this opinion and states that in general, EFL teachers at higher education level in Jordan are highly interested in EFL students' writing performance as the teachers expect their students learning to write English to spell words correctly.

Khuwaileh and Shoumali (2000) state that in order to achieve the objectives of teaching EFL in Jordan, the teachers concentrate their effort towards facilitating them with the necessary linguistic skills and use teaching methods needed for advanced writing performance. The authors add that the students face many difficulties when they write, especially in spelling. They cannot express their ideas because they cannot spell words correctly. These researchers note that there is a problem with the Arab students in writing and spelling. In particular, spelling and pronunciation of the words poses a problem for them, because of the difference between Arabic and English accents and related phonetics. They also note that faced with the spelling handicap, the students can neither write well nor speak fluently.

Looking at the larger ESL scene, Cook (1999) investigated the most common types of spelling errors in the written work of learners of English and the four major types of spelling errors that learners of English commonly make. These errors were categorized broadly into four major errors: omission (leaving letters out), substitution (replacing letters with incorrect ones), transposition (reversing the position of letters), and insertion /addition (including extra letters). He also discusses spelling difficulties and suggests three main problems which are single words, pronunciation-based, and spelling correspondence problems. Single word problems come from the fact that English consists of many individual words and so learners have to study some words individually. Pronunciation-based problems occur when learners do not know the English sound system and therefore use the wrong letters. Spelling correspondence problems, Cook argues, are "the most difficult aspects of English spelling for many students". This is true for native speakers of English too words are harder to spell when the sequence of letters has to be remembered because it does not correspond to the sounds. He highlights four types of spelling errors that learners of English commonly make. These are omissions (leaving letters out), substitutions (replacing letters with incorrect ones), transpositions (reversing the position of letters), and insertion/additions (including extra letters). With specific reference to Arabic, Cook suggests that the most common spelling errors relate to pronunciation and that this is shown through substituted vowels and phonological mistakes.

Arabic learners' problems in English spelling also stem from the differences between the writing systems of Arabic and English (e.g. no capitalisation in Arabic and generally regular correspondence between sounds and letters). These kinds of spelling problems which Arabic speakers have are discussed in more detail in Swan \& Smith (1987) and Kharma \& Hajjaj (1989). The former, for example, highlight problems Arabic learners of English have with the 'mirror' shaped letters (e.g. p and q) and comment on the difficulties which stem from the fact that Arabic is written from right to left (thus learners may write "crwon" rather than crown, "tow" rather than two). Many researchers have investigated various problems encountered by Arab EFL learners, (e. g. Mourtaga 2004; Abdul Haq 1982; Wahba 1998; Abbad 1988; 
Rabab'ah 2003). Several studies have been conducted in Arab countries to investigate lexical, phonological, and syntactic errors made by Arab EFL learners (e.g., Abdul Haq 1982; Wahba 1998; Zughoul/Taminian 1984). Furthermore, many researchers such as, Abdul Haq (1982), Wahba (1998), and Abbad (1988), state that Arab learners of English encounter problems in both speaking and writing. But little has been done on spelling problems. This area of study and research is almost ignored at different levels, for example, at the level of curriculum in universities, syllabi, teaching methods, academic activities like spelling competitions in universities, homework, course assignments, dictionary consultation and so on.

Ideally, the goal of a spelling program should be to develop writers and readers who have spelling consciousness and good spelling habits" (Hillerich, 1977). It's easy to judge if a good spelling program is part of an elementary classroom, secondary classroom or a higher secondary classroom. Simply ask, "Are children in this classroom engaged in the spelling process: finding words, inspecting words, mastering words, and developing good spelling habits?" (Gentry, 1995). In 1957, Lado hypothesized that errors in the second language (L2) are caused by the interference of the student's native language. Such errors reflect the student's inability to separate L1 and L2. Odlin (1989), James (1980), Brown (1987) pointed out that students' errors in L2 are caused by several processes. These include transfer, overgeneralization and communication strategies. Transfer refers to the effect of L1 on the learning of L2. In transfer, patterns from L1 are borrowed. Two types of language transfer were identified: negative transfer and positive transfer. In negative transfer (interference) the use of an L1 pattern or rule leads to an error or inappropriate form in L2. Positive transfer occurs when L1 and L2 have the same form. Positive transfer makes L2 learning easier. In Overgeneralization, patterns may be extended from L2 by analogy. Overgeneralization is a process common in both L1 and L2 learning in which the student extends the use of a grammatical rule of linguistic item beyond its accepted uses, generally by making words or structures follow a more regular pattern. A communication strategy is used to express meanings using the words and grammar which are already known (Ellis 1985; Davies,

Criper, \& Howatt 1984)

\section{Objectives of the Study}

Following objectives were outlined at the start of the study:

(i) To investigate and classify the types of mistakes that Arab students commit in English in Saudi Arabia (at the university level);

(ii) To prove or disprove the hypothesis that Arab EFL learners face MT interference in their acquisition of English spelling;

(iii) To suggest remedial measures to tackle the English spelling problems of the Saudi EFL learners to help them attain greater language proficiency.

\section{Methodology}

The respondents of the study were 26 Arab students of English from the College of Science and Arts, Methnab, Qassim University, Saudi Arabia, 10 of whom from the Intensive Course Programme and the remaining 16 from level 1 ( 8 students) and level 2 ( 8 students). The subjects were administered a dictation of 50 words of which 32 were English words found to be problematic by the researcher in the course of his teaching various levels in the same College. Eight of these had one silent letter. Another eight had consonant clusters. Yet another eight had diphthongs and the remaining eight had homophones. The remaining 18 words bore phonetic spelling. A basic questionnaire to collect demographic data was also requested of them to be filled.

Data was collected during the second semester of the academic session 2014-2015.

\section{Analysis and observations}

Analysis of the responses collected is as follows:

1. Parsing of the words produced show a concentration of errors around diphthongs and silent letter words.

2. $93 \%$ of the responses ( 748 productions out of a total of 832 that was the outcome of problem words dictated to the learners) turned out to be incorrect.

3. Of the 18 phonetically spelt words, $98 \%$ (459 out of 468 responses) were produced correctly. This finding corroborates the hypothesis that Arabic speaking learners of English import the characteristic of the MT (Arabic is written phonetically) on their English learning experience.

4. Responses to the problem words characterized by homophones and consonant clusters showed a success rate of $88 \%$, i.e. Only $12 \%$ of the responses out of a total of 416 were incorrect: Arabic too has the features of homophony and consonant clusters. Learners applied their knowledge of MT on their EFL experience.

\section{Conclusion}

Here is a tale cited by Yule: ...a restaurant manager who has always had trouble with the spelling of English words places an advertisement for a new SEAGH. You see the advertisement and your confusion leads you to ask how he came to form this unfamiliar word. It's very simple, he says. Take the first sound of the word SURE, the middle sound of the word DEAD, and the final sound of the word LAUGH. You will, of course, recognize that this form conveys the pronunciation usually associated with the word chef. 
He says that this unlikely tale may serve as a reminder that the sounds of spoken English do not match up, a lot of time, with letters of written English. This is also the problem dealt by this paper.

English spelling is more complex than Arabic spelling. The English spelling and pronunciation system compared with the Arabic language is different. We may take an example: Arabic is written as it is pronounced, whereas many words in English have silent sounds, and words are multi-syllabic. The students are likely to learn to pronounce the word in the wrong way when their teachers do not pronounce them correctly and where no courses are available containing the rules of spelling, pronunciation, especially in the first levels of study.

The Arab students, in general, have spelling problems because of the differences between English and Arabic sound systems such as, the number and quality of vowels and diphthongs, consonant clusters in word, initial, medial and final positions. The Arabic diacritic system is different from the English language sound system. Further, these learners randomly capitalize word initial letters: Arabic language system does not have any provision of capitalization whether proper nouns or otherwise.

To return to the research questions, we found that this study answered all of the questions. There were four types of spelling errors in students' writing that the students committed: (i) substitution; (ii) omission; (iii) transposition; and (iv) insertion.

The students' perceptions surround their inability to learn English sounds, spellings due also to silent letters in words, and the sentence structure being different from that of Arabic language. They also perceive that there is lack of conducive environment for learning English as teachers also are not equipped with modern teaching tools and IT devices. On being asked to orally sum up their perception of problems with the Saudi education system, the students revealed that the aim is not to learn the language as an educating experience in context to enable students to interact in English, but merely to pass the examinations.

When the teachers' perceptions was sought on the same, we found that their objections relate to the syllabus being outmoded, methods of teaching traditional and lack of modern gadgets and absence of digital system in many cases. The teachers find it difficult at the university level to cope with the deficiency in English because of limited time allotted for the subject and psychological barriers in the grown up students to revert to the basics of the language that they were given at early stage.

\subsection{Recommendations and Suggestions}

(i) Students should be rigorously trained in listening skills.

(ii) The teachers must train the students to 'see' the words and syllables in the mind's eye.

(iii) Extensive use of the dictionary with the aim to help students learn the spelling as well as correct pronunciation of words should be encouraged.

(iv) Time should be allotted to teach phonics and spelling to the EFL learners to reduce the influence of Arabic spelling on English.

(v) Spelling courses should be developed and integrated with the English skills of listening, speaking, reading and writing.

(vi) Word lists and word banks should be assigned to the students to improve their vocabulary.

(vii) Commonly misspelled words should be brought to the notice of students.

(viii) The rules of English spelling should be taught to the learners; the learners should be engaged in language games to help bring clarity of spelling.

(ix) The learners should receive formal instruction in spelling as it is ignored in English courses (in various programmes) at the University level in many parts of the globe.

With these strategies we hope that English spelling errors will decrease and improve language proficiency of the learners. However, further research should be encouraged in the field to unearth the shortcomings, if any, of the recommendations made here.

\section{References}

Abdel Jawad, H. S. (1986). A linguistic analysis of spelling errors made by Jordanian university students, Abhath Al Yarmouk, Yarmouk University, 4(1), 19-31

Mitleb, F., Al Haq, F. \& Al-Jarrah, R (1997). Production of English Sentence Stress by Yarmouk university majors. Journal of the College of Teachers, AlMustansiriah University (Iraq), 9, 121.

AbiSamra, N. (2003). An analysis of errors in Arabic speakers' English writings (Vol. 6, pp. 2008).

Abuhamdia, Z. A. (1995). Coordination in ESL writing: Is its use culturespecific? Multilingual: Journal of Cross Cultural and Inter-language Communication, 14(1), 25-37. http://dx.doi.org/10.1515/mult.1995.14.1.25

AbuSeileek, A. F. (2006). The Use of word processor for teaching writing in EFL learners in King Saud University. Journal of King Saud University. 
AlJabri, F. (2006). Common English spelling difficulties of Omani Learners. Sultanate Of Oman:Ministry of Education.

AlJarf, R. (2010). Spelling error corpora in EFL. Sino US English Teaching, 7(1), 615.

AlJarf, R. (2007) Faulty Strategies of EFL Freshman Spellers. AlSharah, Nayel. (1996). An investigation into EFL students' perceptions of L2 writing in academic settings. Second Language Acquisition and Writing: A multidisciplinary approach. Proceedings. University of Southampton, UK, pp.110124.

Ancker, W. (2000). Errors and Corrective Feedback: Updated Theory and Classroom Practice. English Teaching Forum, 38(4), 20-24.

Badr, M. (1990). Comparing Spelling Mechanisms of Beginning And Pre-Intermediate EFL Students.

Bebout, L. (1985). An error analysis of misspellings made by learners of English as a first and as a second language. Journal of psycholinguistic research, 14(6), 569-593.http://dx.doi.org/10.1007/BF01067386

Botley, S., Hakim, F., \& Dillah, D. (2007) Investigating Spelling Errors In A Malaysian Learner Corpus.Publisher?

Chan, A. Y. W. (2004). Syntactic transfer: Evidence from the interlanguage of Hong Kong Chinese ESL learners. The Modern Language Journal, 88(1), 56-74. http://dx.doi.org/10.1111/j.0026-7902.2004.00218.x

Chiang, P. (1993). How to improve English composition teaching in Taiwan's high schools:A study of error types and learning strategies. Unpublished Master Thesis: National Kaohsiung Normal University.

Yule, G (1996). The Study of Language. Cambridge University Press: Cambridge. 